\title{
Ünal Şentürk, Yaşlılık Sosyolojisi, Yaşlıllğın Toplumsal Yörüngeleri, Bursa: Dora Basım Yayın, 2018, 282 s.
}

Değerlendiren: Hamza Kurtkapan

Türkiye'de yaşlllık sosyolojisi alanında ilk telif eserlerden biri olan ve Ünal Şentürk tarafından kaleme alınan Yaşlllık Sosyolojisi: Yaşlılı̆ı̆n Toplumsal Yörüngeleri isimli kitapta, Türkiye'de nüfusun yaşlanmasının ortaya çıkardığı sosyal ve ekonomik sorunlar ele alınmaktadır. Ancak ele alınan bu sorunlar, kitapta tanıtıcı düzeyin ötesine geçmemiştir. Şentürk, aile, kent ve yaşlllık sosyolojisi alanlarında çalı̧smalar yapmakta ve bu alanlarda İnönü Üniversitesi Sosyoloji Bölümü'nde dersler vermektedir. Yazar, yapmış olduğu teorik ve saha çalışmaları ile ülkemizde yaşllık sosyolojisinin gelişimine katkı sağlamaktadır.

Bu kitap, sosyoloji, gerontoloji, geriatri ve sosyal hizmet bölümleri başta olmak üzere üniversitelerde giderek yaygınlaşan yaşlılık sosyolojisi derslerinde kullanılmak üzere bir kaynak kitap olma potansiyeli taşımaktadır. Zira yazar, bu eserde, yaşlılık sosyolojisi ile ilgili kavram, kuram ve sorun alanlarını tanıtmaktadır. Yaşlılık konusunu, sosyolojiden ödünç alınan sermaye, sınıf ve kuşak gibi kavramlar ile açılama çabası, kitaba literatürde ayrı bir önem kazandırmaktadır. Ancak bu değerlendirme, ansiklopedik düzeyde kalmakta ve ders kitabı özelliğini aşamamaktadır.

Kitabın içeriği birbirleriyle ilişkili üç ana kategoride değerlendirilebilir. Bunların ilki, yaşlllık sosyolojisindeki temel kavram ve kuramlar; ikincisi, gerontoloji ve yaşlılık sosyolojisinin tarihsel gelişimi; sonuncusu ise günümüzde yaşlllığın sosyal görünümleri ve sorunlarıdır. Şentürk, çalışmasının ilk bölümlerinde yaşlllı̆ı tüm boyutları ile tanımlamakta, yaşlllığın biyolojik ve sosyal yönlerini akıcı bir dille açıklamaktadır. Eserde, yaşlılığın çok yönlülüğüne vurgu yapıldıktan sonra bu olgunun sosyal ve tarihsel boyutlarına odaklanılmaktadır. Kitabın sonraki bölümle- 
rinde yaşlllığın modern dönemde görünümleri ele alınmakta ve yaşlllık sosyolojisindeki kuramlar değerlendirilmektedir. Yaşlılığın toplumsal olgu olduğu varsayımı, çalışmanın tüm bölümlerinde hissedilmektedir. Bu çerçevede yaşlılık, kitapta cinsiyet, eğitim, gelir düzeyi ve yaşam yeri gibi toplumsal değişkenlerle birlikte açıklanmaktadır.

Kitapta, yaşl1lık kavramı, Bourdieu'nun sermaye ve habitus analizleri ile değerlendirilmektedir. Şentürk'e göre yaşllıı dönemi, bireyin cinsiyet, eğitim, gelir, kültür ve yaşam biçimlerine göre şekillenmektedir. Bu çerçevede değişen sermaye türlerinin kadın ve erkeklere göre farklılaştığından söz edilmektedir. Yazar, yaşlılık döneminde daha fazla statü ve sosyal sermaye kaybı yaşadıklarından erkeklerin kadınlara oranla daha problemli bir yaşlılık dönemi yaşadıklarını söylemektedir. Ayrıca kitapta, demografik dönüşüm ayrıntılı ve anlaşılır bir dille anlatılmakta ve dünya nüfusunun yaşlandığı, istatistiksel verilerle açıklanmaktadır. Ancak Türkiye'nin bu çizilen tabloda nerede olduğu tam olarak netleştirilmemektedir. Nüfus bilimciler, Türkiye'de demografik dönüşümün önümüzdeki on ylllarda ciddi boyutlara ulaşacağından bahsetmektedirler.

Eserde, gerontolojinin Türkiye'de geldiği aşama ele alınmakta ve bu konuda yapılan çalışmalara yer verilerek literatürdeki gelişmeler, okuyucunun nazarına sunulmaktadır. Kitapta, yaşlılığa dair biyolojik kuramlara kısaca yer verilmekte, toplumsal kuramlar ise ayrıntılı olarak açıklanmaktadır. Yazar, yaşlılık sosyolojisindeki kuramları; yapısal işlevselci, çatışmacı ve yorumsamacı kuramlar başlıkları altında toplamaktadır. Yapısal işlevselci kuramlar içinde; geri çekilme, aktivite, süreklilik, toplumsal rol ve modernite kuramlarını değerlendirmektedir.

Ünal Şentürk kitapta, yaşlılık döneminin önemli sosyal sorunları arasında yer alan ayrımcılık ve dışlanmayı da ele almaktadır. Eserde bu durum iki düzlemde değerlendirilmiştir. Bunlardan ilki, çalışma yaşamından dışlanma, ikincisi ise doğrudan doğruya sosyal yaşamdan uzaklaştırmadır. Ancak kitapta bu konular sadece tanıtım düzeyinde kalmıştır. Yazar, teknolojik ve bilimsel ilerlemeler sonucu ortaya çıkan hızlı değişime ayak uydurmakta zorlanan yaşlıların yaşamın dışına itilmelerini bir yazgı olarak değerlendirmektedir. Eserde, yeni dönem iş piyasasının aradığı özellikler karşısında yeniliklere ayak uyduramama durumunun yaşlıların çalışma yaşamından dışlanmalarına yol açtığı belirtilmektedir. Ancak bu durumun bir sonuç olduğunu ifade etmek gerekmektedir. Bu sonucun bir söyleme dönüşmesinin kendini gerçekleştiren bir kehaneti yaygınlaştıracağını unutmamak gerekmektedir. $\mathrm{Bu}$ eserin bahsedilen söylemin yaygınlaşmasına hizmet edebileceğine dikkat çekmek gerekmektedir. 
Şentürk, kitapta, yaşlıların üretici olmadıkları, ailelerine yük oldukları, hoşgörülü ve esnek olmadıkları gibi bilgi yanlışlarına dikkat çekmektedir. Ayrıca yazar, kitapta, Hans Peter Tews'in yaşlılık kavramlaştırmasını ele almıştır. Tews, yaşlılıkla ilgili beş kavramı öne çıkarmaktadır. Bu kavramlar yaşlılığın "gençleşmesi”, "kadınlaşması", "tekilleşmesi” ile "ileri yaşlılık" ve "meslekten arınmış yaşlılıktır." Yazar, bu bölümde ülkemizde bu özelliklere sahip yaşlı nüfusun oranının giderek artacağ1nı belirttikten sonra bu durumun sosyal, ekonomik ve sağlık alanlarına yansımaları üzerinde yeterince durulmadığından yakınmaktadır. Ancak yazarın kendisi de bu konuya sadece değinmekle yetinmiştir.

Yazarın, kitabın son bölümlerinde yaşlı yalnızlığı ve yaşlı bakımı konularına değinmesi bu konularda çalışacaklara yardımcı olacak niteliktedir. Eserde, yaşlı nüfusun artışına ilişkin en önemli sosyal, ekonomik ve psikolojik konu olan yaşlı bakımına özel bir yer verilmesi, kitabın güçlü yanlarındandır. Kitabın uygulamalı bir çalışma ile desteklenmesi, eseri, yaşlılık sosyolojisi alanında önemli kılmaktadır. Ancak yine de kitaptaki araştırma bulgularının literatürdeki diğer çalışmalar ile daha fazla desteklenmesi, eseri daha güçlü kılabilirdi.

Ünal Şentürk, günümüz yaşlılarını, kuşak kavramı üzerinden analiz etmektedir. Bu çerçevede yazar, baby boom kuşağının özelliklerini ayrıntılı olarak anlatmaktadır. Bu kuşağın yaşam biçimlerinin ve alışkanlıklarının önceki yaşlılardan farklı olduğunu belirtmektedir. Kitapta yazar, günümüzün yaşlılarının daha önceki yaşlı gruplarından farklılaşan özelliklerini, onların baby boom kuşağına mensup olmalarına bağlamaktadır. 1945-1964 yılları arasında doğanlardan oluşan bu kuşağa mensup yaşlıların, kendilerinden önceki yaşlılardan farklı özelliklere sahip oldukları belirtilmektedir. Yazar, bu kuşağa mensup günümüz yaşlılarının daha hareketli, daha iyi fizik ve sağlık koşullarına sahip olduklarını belirtmektedir. Kendi işlerini kendileri yapma eğilimlerini, onların önemli bir özelliği olarak saymaktadır. Yeni yaşlıların piyasa için anlamını ortaya koyan yazar, bu yaşlıların daha önceki yaşlı kuşaklara oranla pazar açısından taşıdığı önem üzerinde durmaktadır. Kitapta bu durum "gümüş ekonomi" kavramı üzerinden açıklanmakta ve yaşlıların üretim ve tüketim potansiyelleri özet bir biçimde değerlendirilmektedir.

Şentürk, Türkiye'de baby boom kuşağına mensup yaşlıların, günümüzdeki ve yakın gelecekteki görünümleri ile bakım ve benzeri ihtiyaçlarına odaklanmaktadır. Yaşlılığın sosyal görünümlerinin, kuşaklar üzerinden değerlendirilmesi, kitabın güçlü yanlarından biridir. Unutulmamalıdır ki yaşlılık çalışmalarında gelişmiş ülkelerde baby boom kuşağının sahip olduğu öneme Türkiye'de "Y kuşağı" sahiptir. Zira Türkiye'de 1980-2000 yılları arasında doğan bu kuşaktakiler, 21. yüzyılın ikin- 
insan \& toplum

ci yarısının yaşlıları olacaktır. Nüfus bilimciler, 2050 sonrasında Türkiye'de ilk defa nüfus içerisinde 65 ve üzeri yaştakilerin oranının 15 yaş ve altı çocuklardan daha fazla olacağını öngörmektedirler. Bundan dolayı Türkiye’de Y Kuşağı yaşlılar, kendilerinden önceki kuşaktakilerden daha fazla dikkat çekicidirler. 